\title{
Factors That Affect The K4 In Indonesia
}

\author{
Kirana Anggraini, Raditya Wratsangka, Krisnawati Bantas, Sandra Fikawati \\ Department of Obstetrics and Gynecology \\ Faculty of Medicine, Trisakty University \\ Jakarta, Indonesia \\ kirana_anggraeni@trisakti.ac.id \\ rwratsangka@ymail.com
}

\begin{abstract}
K4 coverage targets for according to health programs in Indonesia namely of $\mathbf{9 5 \%}$ is still difficult to achieve. From various provinces in Indonesia, only 3 provinces that managed to hit the target, namely the provinces of Jakarta, West Java and Riau. The low coverage of $\mathrm{K} 4$ in various provinces in Indonesia are influenced by various factors. This research aims to know the various factors that affect the $\mathrm{K} 4$ in Indonesia. The design of this research study is cross sectional, with respondents as much 13,955 women aged 15-49 years, which gave birth to the last child in the 5 years prior to the survey. This study uses secondary data, i.e. data from Indonesia Demographic Health Survey (IDHS) in 2012. The data were analyzed using logistic regression analysis. The results showed there were $29.6 \%$ of respondents who have children $>2,14.3 \%$ of respondents who have birth spacing $<3$ years, $16.4 \%$ of respondents aged $<20$ years, 10.9 respondents aged $>35$ years, $60.2 \%$ of respondents who have not finished high school and $38 \%$ of respondents who live below the poverty line. On bivariate analysis, meaningful relationship is obtained between the all confounding variables with a value of $p<0.25$. On multivariate analysis, there is a negative relationship between the intention of pregnancy, the level of economy, the level of education, region of residence, marital status, parity, age, birth spacing and $\mathrm{K} 4$ visits in Indonesia. The rate of the economy is the most dominant variables related to the visit of $\mathrm{K} 4$. The Government is expected to open up new jobs, to lose Indonesia's poor presentation; and also expected to increase socialization and participation of the poor population to become members of the health insurance.
\end{abstract}

Keywords: women; antenatal care; $\mathrm{K} 4$

\section{INTRODUCTION}

In Indonesia, efforts are accelerating the decline in maternal mortality has done so every mother able to access maternal health services. Maternal health services are services provided to pregnant women, conducted by health workers in health care facilities. This service must meet the minimum frequency that is one time in the first trimester (0-12 weeks gestational age), one time in the second trimester (12-24 weeks gestational age), and twice in the third trimester (24 weeks of gestation until birth). Health care of pregnant women must meet the elements of service that includes a weigh weight and height measurements; measurement of blood pressure; measuring upper arm circumference; measurement of the high peaks of the uterus; toksoid tetanus immunization; provide Fe tablet (minimum 90 tablets) during pregnancy; determination of fetal presentation and fetal heart rate; implementation of appointment speech (interpersonal communication and counselling, including family planning); a simple laboratory test services (minimum test blood hemoglobin, urine protein examination and examination of blood type when you have never done before); and case management. The service time is recommended to ensure the protection of pregnant women and the fetus is in the form of early detection of risk factors, prevention, and early treatment of complications of pregnancy. Assessment of the implementation of health care of pregnant women can be done by looking at the coverage of K4, i.e. the number of pregnant women who obtain antenatal services at least four times on the schedule that is recommended in each trimester compared the number of target pregnant women in one region on a one-year period. The indicator shows the ability of pregnant women accessing health services and the level of compliance of pregnant women in checked her pregnancy to health workers [1].

According to the Indonesia Demographic Health Survey 2012 (IDHS 2012), there is an increase in the K4 visits of pregnant women, from 66 percent in 2007 increased to $74 \%$ in 2012 [2]. According to the Ministry of health of the Republic of Indonesia, K4 visits of pregnant women in 2015 is also experiencing an increase compared to the year 2014, from $86.70 \%$ to $87.45 \%$. The increase indicates the improvement of access of communities against health care of pregnant women. K4 coverage have met the targets of the Strategic Plan of the Ministry of health, amounting to $72 \%$, but still below targets for maternal health Program amounting to $95 \%$. In addition, there were five provinces that have not yet reached the target of the Ministry of Health's strategic plan, namely, Papua, West Papua, Maluku, East Nusa Tenggara, and Central Sulawesi. The province successfully hit a target Program of maternal health is Riau, Jakarta and West Java [1].

According to the theory of Planned Behavior (TPB) developed by Ajzen year 1975, the measurement of attitudes, subjective norms and control behavior, can be done to understand the specific factors of forming behavior of women in visit to K4. TPB was developed by Azjen to address measurement that causes the low correlation between attitude and behavior of the Theory of Reason Action (TRA) that already existed before [3]. Factors associated with the intention and behavior of women in the conduct of K4 according to TPB can be divided into three, namely (1) Attitude Toward Behavior that consists of pregnancy intentions, parity, maternal health conditions while pregnant, 
the age of the mother when she was pregnant, the level of education and the level of knowledge about the benefits of pregnancy examination; (2) Subjective Norm consisting of marital status and attitude of health workers; and (3) Perceived Behavioral Control that consists of a level economics, region of residence, employment, affordability of health services, costs of health checks, birth spacing and participation in health insurance.

Various studies which examine about factors related to K4 visits have been conducted at various places. Studies in Ecuador, indicates that pregnancy intentions, region of residence, marital status, parity, level of education, age and economic level related to the visit of K4 [4]. On the research of the systemic review of 28 journals, results of research in developing countries, it brings that level of education of the mother and father, marital status, the cost of inspection, access to medical services, household income, mother's work, exposure to media, history of complications in pregnancy, tradition, pregnancy intention, relates to the behavior of pregnant women in visit K4 [5]. This research aims to know the factors related to the behavior of pregnant women in the conduct of K4 in Indonesia.

\section{METHOD}

Cross sectional design study is done to 13,995 women aged 15-49 years who got pregnant and gave birth to a child last within 5 years prior to the survey. Respondents came from 33 provinces across Indonesia. This research was conducted in January 2017, using 2012 IDHS's data. The research sample is taken from the rest of the respondents who meet the criteria for inclusion and exclusion (total sampling). Criteria for inclusion are all women aged 15-49 years who got pregnant and gave birth to a last child within 5 years prior to the survey. Exclusion criteria of the research is that respondents did not answer the question of research.

Information about the intention of pregnancy, parity, region of residence, marital status, level of education, economic level, birth spacing and the age of respondents obtained by processing information from a list of questions a woman no: 405, 406, 403, 5, 601, 602, 610, 105, 101-123, 217,103 . Information about visit $\mathrm{K} 4$ assessed by processing information from a list of questions a woman no: 412B. Univariate analysis is used to find out the frequency distribution of each variable. Bivariate analysis using logistic regression analysis to get a candidate who will go in the multivariate analysis. Binary logistic regression multivariate analysis model prediction is used to find out the most dominant independent variables related to the visit of K4.

\section{RESULT}

The results show that there are 29.6 percent of respondents have children $>2,14.3$ percent of respondents have a birth spacing $<3$ years, $16.4 \%$ of respondents aged $<20$ years and 10.9 respondents aged $>35$ years. In terms of level of education, there is still a 60.2 percent have not finished high school. On the economic level variables, there are 38 percent respondents who were poor and very poor (Table 1). Bivariate analysis results indicate that the intention of pregnancy, economic level, level of education, a distance of birth, marital status, region of residence, parity and age of the respondents associated significantly with K4 visits with a value of $p<0.25$ (Table 2). On Multivariate analysis, the intention of pregnancy, economic level, level of education, birth spacing, marital status, region of residence, parity and age of the respondents associated significantly with the visit of $\mathrm{K} 4$. The economic level is the dominant factor related to the visit of $\mathrm{K} 4$ (Table 3).

\section{DISCUSSION}

The rate of the economy is the most dominant variable that is associated with the visit of K4. The possibility of a very poor mothers do not do K4 is 4.3 times the probability of very rich mother didn't do K4. The possibility of poor mothers do not do K4 2.4 times the probability of very rich mother didn't do K4. The possibility of middle mother didn't do K4 is 1.9 times the possibility of very rich mother didn't do K4.

TABLE 1. UNIVARIATE ANALYSIS RESULTS

\begin{tabular}{|c|c|}
\hline $\begin{array}{l}\text { Respondent } \\
\text { characteristics }\end{array}$ & $\begin{array}{c}\text { Percent } \\
\text { distribution }\end{array}$ \\
\hline $\begin{array}{l}\text { Pregnancy Intention } \\
\text { Unwanted } \\
\text { Mistimed } \\
\text { Wanted }\end{array}$ & $\begin{array}{l}8.0 \\
7.0 \\
85.0\end{array}$ \\
\hline $\begin{array}{l}\text { Parity } \\
\geq 5 \\
4 \\
3 \\
2 \\
1\end{array}$ & $\begin{array}{c}6.3 \\
7.2 \\
16.1 \\
32.4 \\
38\end{array}$ \\
\hline $\begin{array}{l}\text { Region of Residence } \\
\text { Village } \\
\text { City }\end{array}$ & $\begin{array}{l}49.5 \\
50.5 \\
\end{array}$ \\
\hline $\begin{array}{l}\text { Marital Status } \\
\text { Unmarried } \\
\text { Married } \\
\end{array}$ & $\begin{array}{c}2.9 \\
97.1 \\
\end{array}$ \\
\hline $\begin{array}{l}\text { Educational level } \\
\text { Some Primary } \\
\text { Completed primary } \\
\text { Some secondary } \\
\text { Completed secondary } \\
\text { More than secondary }\end{array}$ & $\begin{array}{c}8.2 \\
24.2 \\
27.8 \\
27.9 \\
11.9 \\
\end{array}$ \\
\hline $\begin{array}{l}\text { Wealth index } \\
\text { Lowest } \\
\text { Second } \\
\text { Middle } \\
\text { Fourth } \\
\text { Highest }\end{array}$ & $\begin{array}{l}19.0 \\
19.8 \\
20.4 \\
21.7 \\
19.1\end{array}$ \\
\hline $\begin{array}{l}\text { Birth Spacing } \\
0 \text { month (first child) } \\
<36 \text { month } \\
37-72 \text { month } \\
>72 \text { month }\end{array}$ & $\begin{array}{l}38.9 \\
14.3 \\
21.6 \\
25.2\end{array}$ \\
\hline $\begin{array}{l}\text { Age } \\
12-20 \text { years } \\
21-29 \text { years } \\
30-35 \text { years } \\
36-48 \text { years }\end{array}$ & $\begin{array}{l}16.4 \\
49.8 \\
31.9 \\
10.9\end{array}$ \\
\hline
\end{tabular}


TABLE 2. BIVARIATE ANALYSIS RESULTS

\begin{tabular}{|c|c|c|c|c|}
\hline \multirow{2}{*}{$\begin{array}{l}\text { Independent } \\
\text { Variable }\end{array}$} & \multirow{2}{*}{ Category } & \multirow{2}{*}{$p$} & \multicolumn{2}{|c|}{\begin{tabular}{|c|} 
Dependent Variable \\
K4 \%
\end{tabular}} \\
\hline & & & Yes & No \\
\hline \multirow[t]{3}{*}{ Pregnancy Intention } & Unwanted & 0.000 & 75.0 & 25.0 \\
\hline & Mistimed & 0.000 & 73.8 & 26.2 \\
\hline & Wanted & & 83.5 & 16.5 \\
\hline \multirow[t]{5}{*}{ Wealth index } & Lowest & 0.000 & 67.7 & 32.3 \\
\hline & Second & 0.203 & 81.0 & 19.0 \\
\hline & Middle & 0.000 & 85.2 & 14.8 \\
\hline & Fourth & 0.000 & 90.9 & 9.1 \\
\hline & Highest & & 93.4 & 6.6 \\
\hline \multirow[t]{5}{*}{ Educational level } & Some Primary & 0.000 & 66.5 & 33.5 \\
\hline & Completed primary & 0.000 & 77.5 & 22.5 \\
\hline & Some secondary & 0.077 & 81.5 & 18.5 \\
\hline & Completed secondary & 0.000 & 87.0 & 13.0 \\
\hline & More than secondary & & 91.1 & 8.9 \\
\hline \multirow[t]{8}{*}{ Birth Spacing } & 0 month & 0.000 & 84.0 & 16.0 \\
\hline & 1-12 month & 0.001 & 67.3 & 32.7 \\
\hline & 13-24 month & 0.000 & 73.4 & 26.6 \\
\hline & $25-36$ month & 0.000 & 74.9 & 25.1 \\
\hline & $37-48$ month & 0.721 & 81.4 & 18.6 \\
\hline & $49-60$ month & 0.205 & 83.9 & 16.1 \\
\hline & 61-72 month & 0.633 & 81.7 & 18.3 \\
\hline & $>72$ month & & 85.0 & 15.0 \\
\hline \multirow[t]{2}{*}{ Marital Status } & Unmarried & 0.000 & 66.8 & 33.2 \\
\hline & Married & & 82.6 & 17.4 \\
\hline \multirow[t]{2}{*}{ Region } & Village & 0.000 & 77.5 & 22.5 \\
\hline & City & & 87.3 & 12.7 \\
\hline \multirow[t]{4}{*}{ Parity } & $\geq 4$ & 0.000 & 73.2 & 26.8 \\
\hline & 3 & 0.012 & 80.3 & 19.7 \\
\hline & 1 & 0.000 & 84.1 & 15.9 \\
\hline & 2 & & 85.5 & 14.5 \\
\hline \multirow[t]{4}{*}{ Age } & $12-20$ years & 0.000 & 74.4 & 25.6 \\
\hline & $21-29$ years & 0.000 & 83.4 & 16.6 \\
\hline & $40-49$ years & 0.000 & 77.0 & 23.0 \\
\hline & 30-39 years & & 83.5 & 16.5 \\
\hline
\end{tabular}

Poverty is defined as a condition where a person or group of people are not able to meet the right of use of the fundamental right to maintain and develop a dignified life. Poverty measurement done by assigning a value to the standard minimum requirement, either for food or for non food that must be met for someone to live in worth. A minimum value of those needs is used as a delimiter to separate the line between poor and not poor. The delimiter line is referred to as the poverty line [1]. The majority of respondents in this research have the economic level of the middle and below the poverty line ( 59.2 percent). On the study of meta-analysis of various journal year 1990-2006 about the relationship between economic levels and K4 visits in developing countries showed similar things.
TABLE 3. THE FINAL RESULTS OF THE MULTIVARIATE ANALYSIS MODEL, THE DOUBLE LOGISTIC REGRESSION TEST MODEL PREDICTIONS

\begin{tabular}{|l|l|c|c|c|c|}
\hline $\begin{array}{l}\text { Independent } \\
\text { Variable }\end{array}$ & Category & $\boldsymbol{p}$ & \multicolumn{3}{|c|}{$\begin{array}{c}\mathbf{9 5 \%} \\
\text { C.I. for } \\
\text { EXP(B) }\end{array}$} \\
\hline Pregnancy Intention & Unwanted & 0.000 & 1.474 & 1.235 & -1.760 \\
& Mistimed & 0.000 & 1.508 & 1.275 & -1.784 \\
\hline Wealth index & Lowest & 0.000 & 4.312 & 3.463 & -5.369 \\
& Second & 0.000 & 2.401 & 1.931 & -2.986 \\
& Middle & 0.000 & 1.975 & 1.586 & -2.460 \\
& Fourth & 0.070 & 1.240 & .983 & -1.564 \\
\hline Educational level & Some Primary & 0.000 & 1.867 & 1.472 & -2.368 \\
& Completed primary & 0.004 & 1.377 & 1.107 & -1.713 \\
& Some secondary & 0.065 & 1.220 & .988 & -1.508 \\
& Completed secondary & 0.289 & 1.118 & .910 & -1.373 \\
\hline Birth Spacing & 0 month & 0.627 & 1.134 & .683 & -1.883 \\
& $1-12$ month & 0.011 & 1.887 & 1.159 & -3.073 \\
& $13-24$ month & 0.000 & 1.607 & 1.317 & -1.961 \\
& $25-36$ month & 0.000 & 1.545 & 1.285 & -1.857 \\
& $37-48$ month & 0.491 & 1.072 & .880 & -1.305 \\
& $49-60$ month & 0.572 & 1.062 & .862 & -1.308 \\
& $61-72$ month & 0.140 & 1.171 & .949 & -1.445 \\
\hline Age & Unmarried & 0.000 & 2.640 & 2.088 & -3.339 \\
\hline Marital Status & Live in Village & 0.018 & 1.143 & 1.024 & -1.276 \\
\hline Region & $\geq 4$ & 0.000 & 1.771 & 1.491 & -2.103 \\
\hline Parity & 3 & 0.000 & 1.507 & 1.297 & -1.752 \\
& 1 & 0.627 & .881 & .529 & -1.468 \\
\hline & $12-20$ years & 0.000 & 2.038 & 1.664 & -2.497 \\
& $21-29$ years & 0.000 & 1.304 & 1.136 & -1.497 \\
& $40-49$ years & 0.130 & 1.236 & .939 & -1.628 \\
\hline
\end{tabular}

There is a meaningful relationship between the levels of economics with the visit of inspection pregnancy. Women with higher economic status has a trend to conduct inspection of the K4 than women with low socioeconomic [5]. This shows that the economic level of the respondent is one thing that is crucial to improve the coverage of the visit of the K4 in Indonesia.

Marital status related to the visit of K4. The possibility of an unmarried mother is not doing the $\mathrm{K} 4$ was 2.6 times the probability of mothers who marry don't do K4. According to Diego, mother's behavior toward his health is affected by the presence of the father of the baby [6]. The majority of respondents in this study were married $(97.1 \%)$, only $2.9 \%$ of respondents who have not married. In studies conducted in Brazil and Ecuador also showed similar things, i.e. unmarried women have greater risk to not do the K4 versus a married woman $[4,6]$.

Other variables related to the visit of $\mathrm{K} 4$ is a birth spacing. The possibility of the mother with the birth spacing $<12$ months not doing $\mathrm{K} 4$ is 1.9 times the probability of mothers with birth spacing $>72$ months does not do the K4. The possibility of the mother with the birth spacing 13-24 months not doing $\mathrm{K} 4$ is 1.6 times the probability of mothers with birth spacing $>72$ months does not do the K4. The 
possibility of the mother with the birth spacing 25-36 months not doing $\mathrm{K} 4$ is 1.5 times the probability of mothers with birth spacing $>72$ months does not do the K4. Studies show an ideal birth spacing is 3 years. Birth spacing can reduce the risk of maternal death, fetal death, neonatal death, anemia due to a previous pregnancy, postpartum endometrium wall inflammation, rupture of the membran, premature birth, low birth weight, intra uterine growth restriction, and malnutrition in the newborn. The study also shows that the shorter birth spacing will be higher risk to not do the visits of K4. Birth spacing settings included in family planning programs to reduce maternal deaths. In this study, there were $14.3 \%$ of respondents who have a birth spacing $<3$ years. In studies conducted in New Jersey shows the same thing, that the increasingly close birth spacing, the fewer inspections of pregnancy [7].

Age was significantly correlated with the visit of K4. The possibility of mothers with 12-20 years of age don't do K4 is 2.0 times the probability of mothers with ages 30-39 years does not do the K4. The possibility of mothers with 21-29 years of age don't do $\mathrm{K} 4$ is 1.3 times the probability of mothers with ages 30-39 years does not do the K4. According to family planning programs, the ideal age for giving birth is not to be too young to give birth (under 20 years) and too old to give birth (over the age of 35 years). In this study, there were 16.4 respondents aged $<20$ years and there are 10.9 respondents aged $>35$ years. In the study conducted in Thailand and Ecuador also showed similar things. Mothers age 21-29 years, $23 \%$ fewer do K4, compared to mothers ages 30-39 years. According to family planning programs, the ideal age for giving birth is not to be too young to give birth (under 20 years) and too old to give birth (over the age of 35 years). In this study, there were 16.4 respondents aged $<20$ years and there are 10.9 respondents aged $>35$ years. In the study conducted in Thailand and Ecuador also showed similar things. In Ecuador, girls aged less than 20 years, much less in doing visits K4 compared girls aged 20-34 years [4]. In Thailand, women aged less than 20 years, is the group most at risk for not doing an examination of $\mathrm{K} 1$, so the total antenatal care visits (K4) is not complete.

Level of education associated with the visit of $\mathrm{K} 4$. The possibility of a mother who has not graduated primary school does not do the $\mathrm{K} 4$ was 1.3 times the probability that mothers school until college did not do K4. The possibility of a mother who graduated primary school does not do the K4 was 1.4 times the probability that mothers school until college did not do K4. Education is an influential component used to make measurements of the level of human development in a country. Changes that occur continuously in the behavior of society caused by the increasing level of education. Education is one of the absolute requirement for the achievement of human development goals. Public education can be measured by a variety of indicators, one of the indicators that can measure the level of public education is the average of the old school. The majority of respondents in this research have not finished elementary school, completed elementary and haven't finished high school (60.2\%). In studies conducted in Ecuador, Thailand, also shows the same thing. In Ecuador, women with primary education over a bit in doing $\mathrm{K} 4$, compared to women who have reached the level of secondary education [4]. In
Thailand, women who have completed elementary school, junior high school and finished high school, more checks K4, than women who are not educated [8].

The possibility of a mother with parity $>4$ doesn't do K4 is 1.7 times the probability of mothers with parity 2 not doing K4. The possibility of a mother with parity 3 doesn't do K4 is 1.5 times the probability of mothers with parity 2 not doing K4. The amount of labor that previously experienced will provide experience on the mother for pregnancy and childbirth. Parity is generally a high barrier for expectant mothers to undertake an examination of pregnancy. This is due to the mother with high parity will be more confident about her pregnancy and feel less need to check pregnancy [5]. The respondents in this study the majority (70.4\%) have children $<2$. However, there is still a $29.6 \%$ of respondents who have $>3$ children, with the largest number of children belonging to the respondents was 13 . In studies conducted in some places also show the same thing. On the study in Ecuador, Karachi and in Kasalsa showed that women with high parity is more risky not to perform an examination of pregnancy compared with women of low parity $[4,9,10]$.

The intention of the pregnancy relate to visit K4. The possibility of mothers with unwanted pregnancies who don't perform $\mathrm{K} 4$ is 1.5 times the probability of mothers with a desired pregnancy that does not do the K4. The possibility of mothers with mistimed pregnancy who don't perform $\mathrm{K} 4$ is 1.5 times the probability of mothers with a desired pregnancy that does not do the K4. According to his intention, then the pregnancy can be distinguished into three, namely the desired pregnancy, unplanned pregnancy, and unwanted pregnancy. Pregnancy called desired (wanted), when pregnancy occurs at the husband and wife who want to have more children. Unplanned pregnancy is called (mistimed), when pregnancy occurs on married couples who still want the pregnancy, however the pregnancy occurs more quickly than planned. Pregnancy is called unwanted, when pregnancy occurs on married couples who already do not want children at all [4]. Research shows that women with unwanted pregnancies, are likely to be fewer checks pregnancy before giving birth, smoking in the third trimester, gave birth to children with low birth weight, and not breast feeding her baby [11]. Children born of mothers who did not want her pregnancy, have worse health and education results. ${ }^{12}$ Women who don't want a pregnancy, appropriate to have worse health outcomes [13]. The respondents in this study, most wanted her pregnancy (85\%). There were some respondents who did not want her pregnancy ( $8 \%$ ) and did not plan her pregnancy (7\%). Studies in various places also show similar things. A study in Ecuador shows that women with unwanted pregnancies, fewer pregnancy checks to health workers, checks on the first trimester of pregnancy, and fewer checks complete pregnancy than women with the desired pregnancy [4]. In studies conducted on a range of samples from the United States and Thailand, showed that women with an unplanned pregnancy and unwanted pregnancy, start examination at a different time than women who wanted pregnancy. Women with an unplanned pregnancy and unwanted, fewer that make a visit to the pregnancy checks to health care than women with the desired pregnancy [14]. 
Other variables related to the visit of $\mathrm{K} 4$ is a region where were living. The possibility of the mother who lives in the village of not doing the $\mathrm{K} 4$ was 1.1 times the probability of mothers who live in the city are not doing K4. According to Simkhada, the woman who lived in the village harder to travel caused by poor road conditions. In addition, the limitation of the number of health workers and uneven distribution in rural areas is also a cause of pregnancy checkup visits are lower than in cities. 5 In Indonesia, the government has conducted various attempts to improve health services for pregnant women at the village level, by the way puts a midwife at the village level as many. In addition, through an Expanding Program of Maternal and Neonatal Survival (EMAS), the expected reference system which efficiently and effectively between clinics and hospitals in 150 hospitals, and 300 clinics in various areas in Indonesia could rise. Nearly half of the respondents in the study lived in villages $(49.5 \%)$, and the rest $(50.5 \%)$ lived in the town. Studies that have been conducted also show similar things. According to a study conducted in Ethiopia, women who live in the city will be doing a pregnancy examination more than women who lived in the village. In another study conducted in Vietnam and Haiti in 2011, obtained a pregnancy Checkup visits are lower in women who live in the countryside than women living in urban areas $[15,16]$.

\section{CONCLUSION}

The intention of pregnancy, parity, region of residence, marital status, levels of education, economic level, birth spacing and the age of the respondents related to the visit of K4. The possibility of unwanted pregnancy by mothers not doing $\mathrm{K} 4$ is 1.5 times the probability of mothers with pregnancy desired does not do the K4. The possibility of mistimed pregnancy by mothers not doing $\mathrm{K} 4$ is 1.5 times the probability of mothers with pregnancy desired does not do the K4. The possibility of a very poor mothers do not do K4 is 4.3 times the probability of very rich mother didn't do K4. The possibility of poor mothers do not do K4 2.4 times the probability of very rich mother didn't do K4. The possibility of mid mother didn't do K4 is 1.9 times the possibility of very rich mother didn't do K4. The possibility of an unmarried mother is not doing the $\mathrm{K} 4$ was 2.6 times the probability of mothers who marry don't do K4. The possibility of the mother with the birth spacing $<12$ months not doing K4 is 1.9 times the probability of mothers with birth spacing $>72$ months does not do the K4. The possibility of the mother with the birth spacing 13-24 months not doing $\mathrm{K} 4$ is 1.6 times the probability of mothers with birth spacing $>72$ months does not do the K4. The possibility of the mother with the birth spacing 25-36 months not doing $\mathrm{K} 4$ is 1.5 times the probability of mothers with birth spacing $>72$ months does not do the $\mathrm{K} 4$. The possibility of mothers with 12-20 years of age don't do K4 is 2.0 times the probability of mothers with ages $30-39$ years does not do the K4. The possibility of mothers with 21-29 years of age don't do K4 is 1.3 times the probability of mothers with ages 30-39 years does not do the K4. The possibility of a mother who has not graduated primary school does not do the $\mathrm{K} 4$ was 1.3 times the probability that mothers school until college did not do K4. The possibility of a mother who graduated primary school does not do the K4 was 1.4 times the probability that mothers school until college did not do K4. The possibility of the mother who lives in the village of not doing the $\mathrm{K} 4$ was 1.1 times the probability of mothers who live in the city are not doing K4. The rate of the economy is the most dominant variables related to the visit of K4.

\section{RECOMMENDATION}

The Government is expected to open up new jobs, especially in Java, Sumatra and other islands to lose Indonesia's poor presentation. In addition, the Government is also expected to increase socialization and participation of the poor population to become members of the health insurance, so that they could benefit from examination of the pregnancy.

The advice against pregnant women is expected to make a visit the pregnancy examination at least one time in the first trimester (0-12 weeks gestational age), one time in the second trimester (12-24 weeks gestational age), and twice in the third trimester ( 24 weeks gestation until birth). Through the early and regular examination, expected to mother and baby can get the maximum benefits of this medical examination. Against the advice of researchers is expected that doing further research on factors related to K4, especially in Papua, West Papua, Maluku, East Nusa Tenggara, Central Sulawesi, and other provinces.

\section{ACKNOWLEDGMENT}

The authors thank the USAID has provided the data for this research. The authors also thank the Trisakti School of medicine who has been giving its support so that this paper can be published.

\section{REFERENCES}

[1] Kementrian Kesehatan Republik Indonesia, Health Statistisc: 2016

[2] Badan Pusat Statistik (BPS), [Indonesia], Badan Koordinasi Keluarga Berencana Nasional (BKKBN), Departemen Kesehatan, dan Macro Internasional. Survei Demografi dan Kesehatan Indonesia 2012. Calverton, Mayrland, USA: BPS dan Macro International; 2013.

[3] Ramdhani Neila, "Penyusunan Alat Pengukur Berbasis Theaory of Planned Behavior," in Buletin Psikologi, vol. 19, No 2, 2011: 56-69

[4] Eggleston, E. Unintended pregnancy and women's use of prenatal care in Ecuador. Social Science and Medicine. 2000; 51:1011-1018.

[5] Simkhada B., Van Teijlingen E.R., Porter M., Simkhada P. Factors affecting the utilization of antenatal care ini developing countries: systematic review of the literature. Journal of Advanced Nursing.2008; 61(3): 244-260.

[6] Diego. Inadequate Use of Prenatal Services Among Brazilian Women: The Role of Maternal Characteristics. International Perspective on Sexual and Reproductive Health. 2009;35(1)

[7] Julien. Prenatal Care and Subsequent Birth Intervals. Perspective on Sexual and Reproductive Health. 2012; 14(1). 
[8] Masmalai, A. The effect of unwanted pregnancy on prenatal practice in Thailand. Journal of Population and social Study. 2010;19:1.

[9] Sohag, A. Factor affecting utilization of antenatal care: the opinion of pregnant women. 2013; PakJPhysiol;9(1)

[10] Aziem, Abdel. Use of antenatal care services in Kassala, eastern Sudan. BMC Pregnancy and Childbirth 2010;10:67.

[11] D'Angelo, D. V., Gilbert, B. C., Rochat, R. W., Santelli, J. S., \& Herold, J. M. Differences between mistimed and unwanted pregnancies among women who have live births. Perspectives on Sexual and Reproductive Health. 2002; 36(5): 192-197

[12] Marston, C., Cleland. Do unintended pregnancies carried to term lead to adverse outcomes for mother and child. An assessment in five developing countries. 2003; 57(1): 77-93.
[13] Barber, J. S., W.G. Axinn, and A. Thornton. Unwanted childbearing, health, and mother-child relationships. Journal of Health and Social Behavior. 1999; 40: 231-257.

[14] Ragupathy, S. Unwanted pregnancies and preventive health care use in Thailand. Population Research and Policy Review. 1997; 16(6): 579595.

[15] K Tran Toan et al. Urban-rural disparities in antenatal care utilization : a study of two cohorts of pregnant women in Vietnam. BMC Health Services Research. 2011; 11:120

[16] PK Alexandre et al. Prenatal care utilization in rural areas and urban areas of Haiti. Panam Salud Publica. 2005; 18(2):84-92. 